\title{
HUBUNGAN LINGKAR PINGGANG DENGAN TEKANAN DARAH MASYARAKAT DI WILAYAH KERJA PUSKESMAS MON GEUDONG TAHUN 2015
}

\author{
Ira Arianti ${ }^{1}$, Cut Asmaul Husna ${ }^{2}$ \\ ${ }^{1}$ Program Studi Kedokteran, Fakultas Kedokteran, Universitas Malikussaleh \\ ${ }^{2}$ Bagian Mikrobiologi, Fakultas Kedokteran Universitas Malikussaleh \\ Corresponding Author : cutasmaulhusnadr@yahoo.co.id
}

\begin{abstract}
Abstrak
Obesitas sentral adalah kondisi kelebihan lemak perut atau lemak pusat. Peningkatan kejadian obesitas sentral berpengaruh pada peningkatan berbagai macam penyakit termasuk hipertensi. Lingkar pinggang merupakan salah satu pengukuran antropometri yang menggambarkan obesitas sentral. Penelitian ini bertujuan untuk mengetahui hubungan lingkar pinggang dengan tekanan darah masyarakat di wilayah kerja Puskesmas Mon Geudong tahun 2015. Jenis penelitian observasional analitik dengan metode cross sectional. Jumlah sampel sebanyak 70 orang berdasarkan kriteria inklusi dan eksklusi. Sampel diambil dengan metode stratified random sampling. Berdasarkan uji statistik, dari 70 orang responden terdapat 15 orang dengan lingkar pinggang normal, terdiri dari $60 \%$ responden dengan tekanan darah normal, $13,3 \%$ pra hipertensi, $20 \%$ hipertensi derajat 1 , dan $6,7 \%$ hipertensi derajat 2 . Responden dengan lingkar pinggang tidak normal didapatkan sebanyak 55 orang, terdiri dari $41,8 \%$ responden dengan tekanan darah normal, 18,2\% prahipertensi, 27,3\% hipertensi derajat 1 dan 12,7\% hipertensi derajat 2. Hasil penelitian menunjukkan tidak terdapat hubungan yang bermakna antara lingkar pinggang dengan tekanan darah ( $p$ value $=0,651)$.
\end{abstract}

Kata kunci : lingkar pinggang; tekanan darah; obesitas sentral; hipertensi

\section{RELATION BETWEEN WAIST CIRCUMFERENCE AND BLOOD PRESSURE AMONG THE PEOPLE AROUND WORKING AREA OF PUSKESMAS MON GEUDONG IN 2015}

\begin{abstract}
Central obesity is the presence of excess fat in the abdomen. Increased incidence of central obesity followed by increased degenerative diseases including hypertension. Waist circumference is one of the anthropometric measurements which describes central obesity. This study determine the relation between waist circumference and blood pressure in Puskesmas Mon Geudong in 2015. This study used analytic observational with cross sectional design. The number of sample in this study were 70 people taken by stratified random sampling method. Based on statistic test, there were 15 respondents with normal waist circumference, consisted of $60 \%$ of normal blood pressure respondents, $13.3 \%$ prehypertension, $20 \%$ grade 1 hypertension and $6.7 \%$ grade 2 hypertension. The respondents with abnormal waist circumference were 55 respondents, consisted of $41.8 \%$ of normal blood pressure respondents, $18.2 \%$ prahypertension, $27.3 \%$ grade 1 hypertension and $12.7 \%$ grade 2 hypertension. The result showed there was no significant relation between waist circumference and blood pressure $(\mathrm{p}$ value $=0.651)$.
\end{abstract}




\section{PENDAHULUAN}

Hipertensi didefinisikan sebagai peningkatan tekanan darah sistolik sedikitnya 140 $\mathrm{mmHg}$ atau tekanan darah diastolik sedikitnya $90 \mathrm{mmHg}$ (Price \& Wilson, 2005). The Seventh Report of The Joint National Committee on Prevention, Detection, Evaluation, and Treatment of High Blood Pressure (JNC VII) mengemukakan bahwa klasifikasi tekanan darah pada orang dewasa terbagi menjadi kelompok normal, prahipertensi, hipertensi derajat 1 dan derajat 2. Hipertensi merupakan penyebab kematian nomor satu di dunia, disusul oleh merokok dan dislipidemia. Hipertensi juga merupakan faktor risiko yang terlibat dalam proses terjadinya mortalitas dan morbiditas dari penyakit kardiovaskular. ${ }^{1}$

World Health Organization (WHO) tahun 2013 menyatakan bahwa prevalensi hipertensi pada tahun 2008 adalah 40\% dari jumlah populasi dewasa di seluruh dunia. Jumlah ini mengalami peningkatan dari sekitar 600 jiwa pada tahun 1998 menjadi sekitar satu miliar jiwa pada tahun $2008 .^{2}$

World Health Organization tahun 2012 menyatakan bahwa hipertensi mengalami peningkatan prevalensi di wilayah Asia Tenggara.Hipertensidi wilayah ini bervariasi yaitu20\% dari jumlah populasi dewasa di Bangladesh dan Korea Utaraserta 45\% dari jumlah populasi dewasa di Indonesia dan Myanmar. Kematian yang diakibatkan oleh penyakit tidak menular di wilayah Asia Tenggara selama tahun 2008 sebanyak 7,9 juta kematian, sekitar 3,6 juta diantaranya disebabkan oleh penyakit jantung dan pembuluh darah. Hal inidiperkirakan meningkat menjadi12,5 juta kematian pada tahun 2030. Hipertensi diderita oleh sekitar sepertiga dari populasi manusia di wilayah Asia Tenggara. ${ }^{3}$

Riset kesehatan dasar (Riskesdas) tahun 2013 mengemukakan bahwa prevalensi hipertensi di Indonesia sebesar 25,8\% dari jumlah total populasi berusia $\geq 18$ tahun. Prevalensi ini mengalami penurunan sebesar 5,9\% dari hasil Riskesdas tahun 2007 yaitu sebesar 31,7\% dari jumlah total populasi berusia $\geq 18$ tahun. Prevalensi hipertensi mengalami penurunan dapat terjadi karena berbagai faktor, diantaranya alat pengukur tekanan darah yang berbeda maupun akibat peningkatan kesadaran masyarakat tentang bahaya hipertensi. ${ }^{4}$

Prevalensi hipertensi di Aceh pada tahun 2013 adalah sebesar 21,5\% dari jumlah total populasi berusia $\geq 18$ tahun. Prevalensi hipertensi yang terdiagnosis oleh tenaga kesehatan dan melalui pengukuran terlihat meningkat dengan bertambahnya usia. Prevalensi hipertensi cenderung lebih tinggi di perkotaan dibandingkan perdesaan serta cenderung lebih tinggi pada kelompok pendidikan rendah dan kelompok tidak bekerja, kemungkinan akibat ketidaktahuan tentang pola makan yang baik. ${ }^{4}$ 
Data dari Dinas Kesehatan Kota Lhokseumawe tahun 2014 didapatkan bahwa hipertensi menempati urutan pertama dari sepuluh penyakit tidak menular terbanyak. Prevalensi hipertensi lebih tinggi pada perempuan dan memperlihatkan peningkatan signifikan pada kelompok usia 35 hingga 44 tahun, serta mencapai puncaknya pada kelompok usia 45 hingga 54 tahun. Data yang mencakup enam Puskesmas yang ada di Kota Lhokseumawe mengungkapkan bahwakejadian hipertensi terbanyak di daerah wilayah kerja Puksesmas Mon Geudong dengan kejadian hipertensi sebanyak 2426 kasus selama tahun 2014. Menurut data wilayah kerja Puskesmas di Kota Lhokseumawe, prevalensi hipertensipada wilayah kerja Puskesmas Mon Geudong selalu meningkat setiap tahunnya. ${ }^{5}$

Obesitas dan pertambahan berat badan merupakan faktor risiko yang kuat untuk hipertensi. Penelitian terdahulu mengemukakan bahwa sekitar $60 \%$ penderita hipertensi mengalami kelebihan berat badan hingga $20 \%{ }^{6}$ Framingham menjelaskan bahwa hipertensi essensial $65 \%$ pada wanita dan $78 \%$ pada pria berhubungan langsung dengan peningkatan berat badan dan obesitas. Jean Vague merupakan ilmuwan pertama yang menyatakan adanya hubungan erat antara perbedaan morfologi tubuh atau tipe distribusi lemak tubuh dengan gangguan kesehatan yang berkaitan dengan faktor risiko obesitas. ${ }^{7}$ Studi prospektif menyatakan bahwa obesitas tubuh bagian atas (obesitas sentral) berhubungan lebih kuat dengan intoleransi glukosa/ diabetes melitus, hiperinsulinemia, hipertensi, hipertrigliseridemia, dan gout dibandingkan obesitas tubuh bagian bawah. ${ }^{8}$

Banyaknya lemak dalam perut menunjukkan ada beberapa perubahan metabolisme termasuk daya tahan terhadap insulin dan meningkatnya produksi asam lemak bebas, dibanding dengan banyaknya lemak bawah kulit atau pada kaki dan tangan. Perubahan metabolisme ini memberikan gambaran tentang pemeriksaan penyakit yang berhubungan dengan distribusi lemak tubuh. ${ }^{9}$

Hasil Riskesdas tahun 2013 mengemukakan bahwa secara nasional prevalensi obesitas sentral mengalami peningkatan sebesar 7,8\% dari sekitar 18,8\% pada tahun 2007 menjadi 26,6\% pada tahun 2013. Prevalensi obesitas sentral nasional pada tahun 2013 didapatkan lebih banyak pada perempuan (42,1\%) dibandingkan laki- laki (11,3\%). Prevalensi obesitas sentral untuk Provinsi Aceh pada tahun 2013 adalah 26\%, sedikit lebih rendah dari prevalensi obesitas sentral nasional. ${ }^{4}$

Hasil penelitian di negara berkembang menunjukkan bahwa peningkatan lemak tubuh secara signifikan terjadi di atas usia 30 tahun. Peningkatan maksimum terjadi pada usia 35 hingga 44 tahun pada laki- laki, sedangkan pada perempuan hal ini terjadi 10 tahun lebih lama. $^{10}$ 
Berbagai metode pengukuran antropometri tubuh dapat digunakan sebagai skrining obesitas. Metode tersebut antara lain pengukuran indeks massa tubuh (IMT), lingkar pinggang, lingkar panggul, lingkar lengan, serta perbandingan lingkar pinggang dan lingkar panggul. Lingkar pinggang merupakan pengukur distribusi lemak abdominal yang mempunyai hubungan erat dengan indeks massa tubuh. ${ }^{11}$

Lingkar pinggangdapat menjadiparameterpilihan untukmemprediksisindrom metabolikdibandingkan denganIMTdanrasio lingkar pinggang panggul. ${ }^{12}$ Lingkar pinggang adalah ukuran antropometri yang dapat digunakan untuk menentukan obesitas sentral. Kriteria ukuran lingkar pinggang untuk Asia Pasifik yaitu $\geq 90 \mathrm{~cm}$ untuk pria, dan $\ 80 \mathrm{~cm}$ untuk wanita. ${ }^{10}$ Pengukuran lingkar pinggang dapat menggambarkan keberadaan lemak berbahaya dalam dinding abdomen tiga kali lebih besar dibandingkan IMT. ${ }^{13}$ Pengukuran lingkar pinggang dapat digunakan sebagai salah satu indeks distribusi lemak tubuh serta dapat digunakan untuk mengidentifikasi individu dengan kelebihan berat badan dan obesitas yang merupakan salah satu faktor risiko terjadinya hipertensi.Oleh karena itu, peneliti tertarik untuk mengetahui hubungan antara lingkar pinggang dengan tekanan darah masyarakat di wilayah kerja Puskesmas Mon Geudong tahun 2015.

\section{METODE}

Penelitian ini merupakan penelitian observasional analitik dengan rancangan potong lintang (cross sectional). Sampel dalam penelitian ini adalah masyarakat yang bertempat tinggal di dalam wilayah kerja Mon Geudong Kota Lhokseumawe yang diambil dengan carastratifeid random sampling. Penelitian ini dilakukan di desa yang termasuk dalam wilayah kerja puskesmas Mon Geudong, yaitu Desa Pusong lama, Pusong Baru, Mon Geudong, Keude Aceh, Simpang Empat, dan Desa Kota Lhokseumawe.

A. Instrumen penelitian

\section{Informed consent.}

2. Tekanan darah.
a. Sfigmomanometer merek Riester Nova-Presameter ${ }^{\circledR}$.
b. Stetoskop merek Littmann ${ }^{\circledR}$ Stethoscopes.

3. Lingkar pinggang.

a. Tape measuring/meterline.

B. Cara Kerja

1. Cara Pengukuran Tekanan Darah 
a. Memperkenalkan diri dan menjelaskan cara serta tujuan pengukuran tekanan darah pada pasien.

b. Sebelum melakukan pengukuran tekanan darah, pasien sebaiknya menghindari aktivitas fisik seperti olahraga, merokok dan makan minimal 30 menit sebelum pengukuran serta duduk beristirahat setidaknya 5 hingga 15 menit sebelum pengukuran. Pastikan pasien sedang dalam keadaan tidak ingin berkemih.

c. Hindari melakukan pengukuran dalam kondisi stres.Pengukuran sebaiknya dilakukan dalam ruangan dan kondisi yang tenang serta dalam posisi duduk.

d. Pastikan pasien duduk dengan posisi kaki tidak menyilang dan posisikan kedua telapak kaki datar menyentuh lantai.

e. Letakkan lengan kanan pasien di atas meja.Posisikan lengan kanan pasien sedikit fleksi dan lengan atas setinggi jantung.

f. Singkirkan lengan baju pada lengan bagian kanan pasien dan memintanya untuk tetap duduk tanpa banyak bergerak dan tidak berbicara pada saat pengukuran. Apabila pasien menggunakan baju berlengan panjang, singkirkan lengan baju ke atas tetapi pastikan lipatan baju tidak terlalu ketat sehingga tidak menghambat aliran darah di lengan.

g. Letakkan manset mengelilingi lengan pasien bagian atas dengan selang berada di bagian depan dan selipkan bagian penjepitnya, atau tutup dengan klip yang sudah tersedia.

h. Biarkan lengan dalam posisi tidak tegang dengan telapak tangan terbuka ke atas.Pastikan tidak ada lekukan pada pipa manset.

i. Hubungkan manometer dengan manset.

j. Rasakan dengan tangan pemeriksa yang lain adanya denyutan pada pergelangan tangan pasien, tutup katup yang berada pada gelembung karet dan pompakan manset sampai pemeriksa tidak dapat lagi merasakan denyutan. Ini merupakan taksiran tekanan darah sistolik sehingga memberi gambaran bagi pemeriksa berapa tekanan yang diperlukan untuk mengembangkan manset ketika mengukur tekanan darah aktual karena pengembangan manset yang berlebihan dapat menyebabkan ketidaknyamanan bagi pasien.

k. Kempiskan manset dan rasakan adanya denyutan di lekukan lengan.

1. Letakkan sisi stetoskop yang berfungsi untuk mendengar di telinga pemeriksa dan bagian ujung stetoskop pada arteri di lekukan lengan pasien. 
m. Tutup katup dan kembangkan manset sampai skala yang terbaca berada di atas tekanan sistolik saat palpasi sebelumnya.

n. Kemudian longgarkan katup dan kempiskan manset secara perlahan-lahan. Saat pemeriksa melakukannya, maka akan terdengar tekanan sistolik yang berupa suara turbulensi dan catat pada tekanan berapa suara itu mulai terdengar.

o. Semakin lama maka akan terdengar suara murmur yang merupakan suara tekanan diastolik. Catat pada tekanan berapa suara murmur tersebut terdengar hingga suara tidak tedengar lagi.

p. Catat hasil pengukuran pada lembar catatan observasi pengukuran tekanan darah.

q. Lepaskan manset dan kempiskan manset dengan tangan untuk mengeluarkan udara dalam manset.

r. Pengukuran dilakukan dua kali untuk mengambil rata-ratanya. Jarak antara dua pengukuran sebaiknya minimal 2 menit oleh orang yang sama dengan melepaskan mancet pada lengan.

s. Setelah pengukuran selesai, rapikan pasien dan alat.

t. Interpretasi hasil pengukuran tekanan darah dalam penelitian ini menggunakan kriteria JNC VII berdasarkan rekomendasi Riset Kesehatan Dasar (Rikesdas).

2. Cara mengukur lingkar pinggang

a. Jelaskan pada pasien tujuan pengukuran lingkar pinggang dan tindakan apa saja yang akan dilakukan dalam pengukuran.

b. Pasien diminta dengan cara yang santun untuk membuka atau mengangkat pakaian bagian atas dan raba tulang rusuk terakhir responden untuk menetapkan titik pengukuran.

c. Tetapkan titik batas tepi tulang rusuk paling bawah.

d. Tetapkan titik ujung lengkung tulang pangkal paha atau panggul.

e. Tetapkan titik tengah diantara titik tulang rusuk terakhir titik ujung lengkung tulang pangkal paha atau panggul dan tandai titik tengah tersebut dengan alat tulis.

f. Minta pasien untuk berdiri tegak dan melakukan ekspirasi normal.

g. Lakukan pengukuran lingkar perut dimulai atau diambil diambil dari titik tengah kemudian secara sejajar horizontal melingkari pinggang dan perut kembali menuju titik tengah di awal pengukuran. 
h. Pengukuran dilakukan pada saat akhir ekspirasi dengan kedua tungkai dilebarkan 20 hingga $30 \mathrm{~cm}$ dan pasien diminta untuk tidak menahan perutnya saat pengukuran dilakukan.

i. Apabila pasien mempunyai perut yang buncit ke bawah, pengukuran mengambil bagian yang paling buncit lalu berakhir pada titik tengah tersebut lagi.

j. Pita pengukur tidak boleh terlipat dan ukur lingkar pinggang mendekati angka $0,1 \mathrm{~cm}$.

k. Menginterpretasikan hasil tes dengan ketentuan:

a. Normal

Interpretasi normal diberikan jika didapatkan hasil pengukuran lingkar pinggang $<90 \mathrm{~cm}$ pada pria dan $<80 \mathrm{~cm}$ pada wanita.

b. Tidak normal

Interpretasi tidak normal diberikan jika didapatkan hasil pengukuran lingkar pinggang $\searrow 90 \mathrm{~cm}$ pada pria dan $\geq 80 \mathrm{~cm}$ pada wanita.

\section{HASIL PENELITIAN}

Penelitian ini dilakukan di wilayah kerja Puskesmas Mon Geudong yaitu Pusong Lama, Pusong Baru, Keude Aceh, Kota Lhokseumawe, Simpang empat, dan Mon Geudong. Keenam wilayah kerja Puskesmas Mon Geudong tersebut termasuk dalam pembagian daerah Kemukiman Lhokseumawe Selatan. Sampel yang diambil kemudian

A. Karakteristik Responden

Tabel 1 Karakteristik Responden

\begin{tabular}{ccc}
\hline \multicolumn{1}{c}{ Karakteristik } & $\mathrm{n}$ & $\%$ \\
\hline Kelompok Usia & 11 & 15,7 \\
$-\quad 25-34$ & 32 & 45,7 \\
$-\quad 35-44$ & 20 & 28,6 \\
$-\quad 45-54$ & 7 & 10 \\
- 55-64 & & \\
Jenis kelamin & 63 & 90 \\
- Perempuan & 7 & 10 \\
- Laki-laki & & \\
Tekanan darah & 32 & 45,7 \\
- Normal & 12 & 17,1 \\
- Prahipertensi & 18 & 25,7 \\
- Hipertensi derajat 1 & 8 & 11,4 \\
- Hipertensi derajat 2 & & 21,4 \\
Lingkar pinggang & 15 & 78,6 \\
- Normal & 55 & \\
- Tidak normal & &
\end{tabular}


Tabel 1 menunjukkan dari 70 orang responden, kelompok usia 35-44 tahun (45,7\%) adalah kelompok mayoritas. Jenis kelamin terbanyak adalah perempuan (90\%). Responden lebih banyak memiliki tekanan darah normal $(45,7 \%)$ dan ukuran lingkar pinggang yang tidak normal $(78,6 \%)$

B. Karakteristik Tekanan Darah Responden.

Tabel 2 Karakteristik Tekanan Darah Berdasarkan Usia Responden

\begin{tabular}{|c|c|c|c|c|c|c|c|c|c|c|}
\hline \multirow{3}{*}{ Usia } & \multicolumn{8}{|c|}{ Tekanan Darah } & \multirow{2}{*}{\multicolumn{2}{|c|}{ Total }} \\
\hline & \multicolumn{2}{|c|}{ Normal } & \multicolumn{2}{|c|}{ Prahipertensi } & \multicolumn{2}{|c|}{$\begin{array}{l}\text { Hipertensi } \\
\text { Derajat } 1\end{array}$} & \multicolumn{2}{|c|}{$\begin{array}{c}\text { Hipertensi } \\
\text { Derajat } 2\end{array}$} & & \\
\hline & $\mathrm{n}$ & $\%$ & $\mathrm{n}$ & $\%$ & $\mathrm{n}$ & $\%$ & $\mathrm{n}$ & $\%$ & $\mathrm{n}$ & $\%$ \\
\hline $25-34$ & 9 & 81,8 & 1 & 9,1 & 1 & 9,1 & 0 & 0 & 11 & 100 \\
\hline $35-44$ & 16 & 50 & 6 & 18,8 & 9 & 28,1 & 1 & 3,1 & 32 & 100 \\
\hline $45-54$ & 4 & 20 & 4 & 20 & 6 & 30 & 6 & 30 & 20 & 100 \\
\hline $55-64$ & 3 & 42,9 & 1 & 14,3 & 2 & 28,6 & 1 & 14,3 & 7 & 100 \\
\hline Total & & & & & & & & & 70 & 100 \\
\hline
\end{tabular}

Tabel 2 menunjukkan karakteristik responden dengan kelompok usia 25-34 tahun, kelompok usia 35-44 tahun dan kelompok usia 55-64 tahun lebih banyak memiliki tekanan darah normal. Kelompok usia 45-54 tahun cenderung memiliki tekanan darah hipertensi derajat 1 dan hipertensi derajat 2.

Tabel3 Karakteristik Tekanan Darah Berdasarkan Jenis Kelamin Responden

\begin{tabular}{|c|c|c|c|c|c|c|c|c|c|c|}
\hline \multirow{3}{*}{$\begin{array}{c}\text { Jenis } \\
\text { Kelamin }\end{array}$} & \multicolumn{8}{|c|}{ Tekanan Darah } & \multirow{2}{*}{\multicolumn{2}{|c|}{ Total }} \\
\hline & \multicolumn{2}{|c|}{ Normal } & \multicolumn{2}{|c|}{ Prahipertensi } & \multicolumn{2}{|c|}{$\begin{array}{l}\text { Hipertensi } \\
\text { Derajat } 1\end{array}$} & \multicolumn{2}{|c|}{$\begin{array}{l}\text { Hipertensi } \\
\text { Derajat } 2 \\
\end{array}$} & & \\
\hline & $\mathrm{n}$ & $\%$ & $\mathrm{n}$ & $\%$ & $\mathrm{n}$ & $\%$ & $\mathrm{n}$ & $\%$ & $\mathrm{n}$ & $\%$ \\
\hline Perempuan & 29 & 46 & 10 & 15,9 & 16 & 25,4 & 8 & 12,7 & 63 & 100 \\
\hline Laki-laki & 3 & 42,9 & 2 & 28,6 & 2 & 28,6 & 0 & 0 & 7 & 100 \\
\hline Total & & & & & & & & & 70 & 100 \\
\hline
\end{tabular}

Tabel 3 menunjukkan responden perempuan lebih banyak memiliki tekanan darah yang normal $(46 \%)$ dan responden laki-laki lebih banyak memiliki tekanan darah normal $(42,9 \%)$.

C. Karakteristik Lingkar Pinggang Responden 
Tabel 4 Karakteristik Lingkar Pinggang Berdasarkan Usia Responden

\begin{tabular}{ccccccc}
\hline & \multicolumn{4}{c}{ Lingkar pinggang } & \multicolumn{3}{c}{ Total } \\
\cline { 2 - 5 } Usia & \multicolumn{2}{c}{ Normal } & \multicolumn{2}{c}{ Tidak Normal } & \multicolumn{2}{c}{} \\
\cline { 2 - 5 } & $\mathrm{N}$ & $\%$ & $\mathrm{n}$ & $\%$ & $\mathrm{n}$ & $\%$ \\
\hline $25-34$ & 2 & 18,2 & 9 & 81,8 & 11 & 100 \\
$35-44$ & 8 & 25 & 24 & 75 & 32 & 100 \\
$45-54$ & 2 & 10 & 18 & 90 & 20 & 100 \\
$55-64$ & 3 & 42,9 & 4 & 57,1 & 7 & 100 \\
Total & & & & & 70 & 100 \\
\hline
\end{tabular}

Tabel 4 menunjukkan bahwa kelompok usia 55-64 tahun merupakan kelompok mayoritas dengan lingkar pinggang normal (42,9\%). Kelompok usia 45-54 tahun merupakan kelompok yang paling banyak memiliki lingkar pinggang tidak normal (90\%).

Tabel 5 Karakteristik Lingkar Pinggang Berdasarkan Jenis Kelamin Responden

\begin{tabular}{|c|c|c|c|c|c|c|}
\hline \multirow{3}{*}{ Jenis Kelamin } & \multicolumn{4}{|c|}{ Lingkar Pinggang } & \multirow{2}{*}{\multicolumn{2}{|c|}{ Total }} \\
\hline & \multicolumn{2}{|c|}{ Normal } & \multicolumn{2}{|c|}{ Tidak Normal } & & \\
\hline & $\mathrm{n}$ & $\%$ & $\mathrm{~N}$ & $\%$ & $\mathrm{n}$ & $\%$ \\
\hline Perempuan & 9 & 14,3 & 54 & 85,7 & 63 & 100 \\
\hline Laki-laki & 6 & 85,7 & 1 & 14,3 & 7 & 100 \\
\hline Total & & & & & 70 & 100 \\
\hline
\end{tabular}

Tabel 5 menunjukkan responden perempuan lebih banyak memiliki lingkar pinggang yang tidak normal $(85,7 \%)$, sedangkan responden laki-laki lebih banyak memiliki lingkar pinggang normal $(85,7 \%)$.

D. Hubungan Lingkar Pinggang dengan Tekanan Darah Masyarakat di Wilayah Kerja Puskesmas Mon Geudong Tahun 2015

Tabel 5.6 Hubungan Lingkar Pinggang dengan Tekanan Darah Masyarakat di Wilayah Kerja Puskesmas Mon Geudong Tahun 2015

\begin{tabular}{|c|c|c|c|c|c|c|c|c|c|c|c|}
\hline \multirow{3}{*}{$\begin{array}{l}\text { Lingkar } \\
\text { Pinggang }\end{array}$} & \multicolumn{8}{|c|}{ Tekanan Darah } & \multirow{2}{*}{\multicolumn{2}{|c|}{ Total }} & \multirow{3}{*}{$p$ value } \\
\hline & \multicolumn{2}{|c|}{ Normal } & \multicolumn{2}{|c|}{$\begin{array}{c}\text { Prahiper } \\
\text { Tensi }\end{array}$} & \multicolumn{2}{|c|}{$\begin{array}{c}\text { Hipertensi } \\
\text { Derajat } 1\end{array}$} & \multicolumn{2}{|c|}{$\begin{array}{l}\text { Hipertensi } \\
\text { Derajat } 2\end{array}$} & & & \\
\hline & $\mathrm{n}$ & $\%$ & $\mathrm{n}$ & $\%$ & $\mathrm{n}$ & $\%$ & $\mathrm{n}$ & $\%$ & $\mathrm{n}$ & $\%$ & \\
\hline Normal & 9 & 60 & 2 & $\begin{array}{c}13 \\
3\end{array}$ & 3 & 20 & 1 & 6,7 & $\begin{array}{l}1 \\
5\end{array}$ & $\begin{array}{c}10 \\
0\end{array}$ & \\
\hline $\begin{array}{l}\text { Tidak } \\
\text { Normal }\end{array}$ & 23 & 41,8 & 10 & $\begin{array}{c}18, \\
2\end{array}$ & 15 & 27,3 & 7 & 12,7 & $\begin{array}{l}5 \\
5\end{array}$ & $\begin{array}{c}0 \\
0 \\
0\end{array}$ & 0,651 \\
\hline Total & & & & & & & & & $\begin{array}{l}7 \\
0\end{array}$ & $\begin{array}{c}10 \\
0\end{array}$ & \\
\hline
\end{tabular}

Tabel 5.6 menunjukkan bahwa responden dengan lingkar pinggang normal dan lingkar pinggang tidak normal cenderung memiliki tekanan darah normal. Berdasarkan uji statistik 
Pearson Chi Square yang telah dilakukan antara variabel lingkar pinggang dan tekanan darah, diperoleh $p$ value $=0,651$. Hal ini menunjukkan bahwa tidak terdapat hubungan antara lingkar pinggang dengan tekanan darah masyarakat di wilayah kerja Puskesmas Mon Geudong Tahun 2015.

\section{PEMBAHASAN}

Hasil penelitian ini menunjukkan bahwa responden dengan kelompok usia yang lebih tua cenderung memiliki tekanan darah hipertensi yang lebih banyak daripada kelompok usia yang lebih muda. Tekanan darah hipertensi derajat 1 dan derajat 2 didominasi pada kelompok usia 45-54 tahun. Hal ini sejalan dengan penelitian yang dilakukan oleh Anggara dan Prayitno yang menunjukkan bahwa tekanan darah hipertensi cenderung terdapat pada subjek dengan

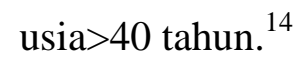

Bustan mengemukakan bahwa kecenderungan peningkatan prevalensi hipertensi meningkat menurut peningkatan usia dan biasanya pada usia $\geq 40$ tahun. ${ }^{15} \mathrm{Hal}$ ini disebabkan karena tekanan arterial yang meningkat sesuai dengan bertambahnya usia, terjadinya regurgitasi aorta, serta adanya proses degeneratif, yang lebih sering pada usia tua. Pertambahan usia akan meningkatkan risiko penyakit yang meliputi kelainan saraf atau kejiwaan, kelainan jantung dan pembuluh darah serta berkurangnya fungsi panca indera dan kelainan metabolisme pada tubuh. ${ }^{16}$ Teori ini didukung oleh Andres dan Tobin yang mengemukakan hukum $1 \%$. Hukum ini menyatakan bahwa fungsi organ-organ akan menurun sebanyak $1 \%$ setiap tahunnya setelah usia 30 tahun. ${ }^{17}$

Usia berpengaruh pada risiko penyakit kardiovaskular karena dapat menyebabkan perubahan pada jantung dan pembuluh darah. Tekanan darah meningkat sesuai usia karena arteri secara perlahan akan kehilangan elastisitasnya. Lanjut usia (lansia) biasanya akan menjadi kurang aktif sehingga berat badan meningkat. Pengaruh gaya hidup yang kurang gerak dan merokok mempercepat kerusakan jantung serta sirkulasi darah dan kadar kolesterol. $^{18}$

Hasil penelitian ini menunjukkan bahwa responden dengan jenis kelamin perempuan dan laki-laki cenderung memiliki tekanan darah normal.Hal ini sejalan dengan penelitian yang dilakukan oleh Anggara dan Prayitnoyang menyatakan bahwa tidak terdapat perbedaan tekanan darah antara subjek perempuan dengan subjek laki-laki. ${ }^{14}$ Tidak terdapat bukti nyata tentang adanya perbedaan tekanan darah antara pria dan wanita pada usia dini, akan tetapi mulai masa remaja, wanita cenderung menunjukkan rata-rata tekanan darah yang lebih tinggi. Perbedaan ini lebih jelas pada dewasa muda.Kejadian hipertensi pada wanita postmenopause 
cenderung menyamai bahkan lebih tinggi dari pria karena efek protektif hormon estrogen yang menurun. Sensitivitas garam pada tekanan darah meningkatkan risiko terjadinya hipertensi dan penyakit kardiovaskuler. ${ }^{19}$

Hasil penelitian ini menunjukkan bahwa responden dengan kelompok usia yang lebih tua cenderung memiliki lingkar pinggang yang tidak normal. Responden dengan kelompok usia 45-54 tahun merupakan kelompok mayoritas yang memiliki lingkar pinggang tidak normal. Hal ini sejalan dengan penelitian yang dilakukan oleh Sugianti yang menyatakan bahwa usia 35-54 tahun dan usia $\geq 55$ tahun berpeluang mengalami obesitas sentral lebih besar dibandingkan usia 15-34 tahun. ${ }^{20}$

Peningkatan kebutuhan lemak terjadi pada usia yang lebih tua karena meningkatnya total lemak tubuh, persentase massa tubuh, dan deposit lemak di viseral yang dapat berpengaruh pada ukuran lingkar pinggang serta penyebaran lemak pada lansia. ${ }^{21}$ Kejadian obesitas sentral meningkat seiring dengan bertambahnya usia seseorang akibat penumpukan lemak tubuh terutama lemak pusat. $^{22}$

Penumpukan lemak perut terjadi akibat perubahan beberapa jenis hormon dan penurunan massa otot pada usia yang lebih tua. ${ }^{23}$ Selain itu, pada usia 40-59 tahun seseorang cenderung mengalami obesitas dibandingkan dengan umur yang lebih muda yang disebabkan oleh lambatnya metabolisme, kurangnya aktivitas fisik dan frekuensi konsumsi pangan yang lebih sering. Selain itu, orang tua biasanya tidak begitu memerhatikan ukuran tubuhnya. ${ }^{24}$

Hasil penelitian ini menunjukkan bahwa responden perempuan lebih banyak memiliki lingkar pinggang yang tidak normal dibandingkan responden laki-laki.Hal ini sejalan dengan penelitian yang dilakukan oleh Lipoeto et al yang mendapatkan bahwa obesitas sentral lebih banyak terjadi pada perempuan dibandingkan laki-laki. ${ }^{25}$ Hal ini juga sejalan dengan pengukuran yang dilakukan oleh Dinas Kesehatan Kota Lhokseumaweyang menyatakan bahwa obesitas sentral lebih banyak terjadi pada jenis kelamin perempuan. ${ }^{5}$ Penelitian oleh Amelinda dan Wirawanni juga menyatakan bahwa lingkar pinggang tidak normal berisiko lebih banyak terdapat pada wanita. ${ }^{26} \mathrm{Hal}$ ini diduga karena lebih tinggi cadangan lemak tubuh wanita dibandingkan pria.

Tingginya kejadian obesitas sentral pada wanita dibandingkan pria karena adanya perbedaan tingkat aktivitas fisik dan asupan energi pada pria dan wanita. ${ }^{23}$ Wanita mengontrol kelebihan energi sebagai lemak simpanan, sedangkan pria menggunakan kelebihan energinya untuk mensintesis protein. Pola penggunaan energi untuk keseimbangan energi positif dan deposit lemak pada wanita disebabkan oleh dua alasan. Pertama, penyimpanan lemak jauh lebih efisien daripada protein. Kedua, penyimpanan energi sebagai lemak akan berperan pada 
rendahnya rasio jaringan bebas lemak dengan jaringan lemak dengan hasil tidak meningkatnya Resting Metabolite Rate (RMR) pada kecepatan yang sama sebagai massa tubuh. $^{27}$

Berdasarkan uji statistik Pearson Chi Square, didapatkan responden dengan lingkar pinggang normal dan lingkar pinggang tidak normal lebih banyak memiliki tekanan darah nomal. Uji Chi square didapatkan nilaip value sebesar 0,651. Hal ini berarti H0 gagal ditolak, berarti tidak terdapat hubungan antara lingkar pinggang dengan tekanan darah.Penelitian ini sesuai dengan hasil penelitian yang diperoleh dari Kautsar, Syam dan Salam yang menyatakan tidak terdapat hubungan antara lingkar pinggang dengan tekanan darah.Penelitian tersebut menggunakan sampel sebanyak 71 orang dan didapatkan nilai $p$ value sebesar $0,716 .^{28}$ Penelitian ini juga sejalan dengan hasil penelitian yang dilakukan oleh Oviyanti.Penelitian tersebut juga menyatakan bahwa tidak terdapat hubungan antara lingkar pinggang dengan tekanan darah. ${ }^{29}$

Penelitian ini berbeda dengan penelitian yang dilakukan oleh Yalcin dan Sahin, dan penelitian yang dilakukan oleh Jalal et al yang menyatakan terdapat hubungan antara lingkar pinggang dengan tekanan darah. ${ }^{30,10}$ Perbedaan hasil dari kedua penelitian ini kemungkinan disebabkan oleh adanya perbedaan dalam usia sampel dan juga besar sampel yang diteliti.

Tidak terdapatnya hubungan yang bermakna dalam penelitian ini kemungkinan dikarenakan banyaknya faktor risiko lain penyebab hipertensi yang tidak dapat diubah seperti faktor keturunan atau genetik. Periode penelitian ini juga pendek sehingga menyebabkan jumlah sampel yang digunakan juga sedikit.Jumlah responden dengan jenis kelamin laki-laki dalam peelitian ini jauh lebih sedikit dibandingkan perempuan karena kesulitan peneliti dalam mengumpulkan sampel laki-laki yang sesuai dengan kriteria penelitian.

\section{KESIMPULAN}

A. Kesimpulan

Berdasarkan penelitian yang dilakukan, maka dapat disimpulkan bahwa:

1. Kelompok usia 25-34 tahun merupakan kelompok mayoritas dengan tekanan darah normal. Responden dengan kelompok usia 45-54 tahun merupakan kelompok terbanyak dengan tekanan darah hipertensi derajat 1 dan hipertensi derajat 2 .

2. Kedua jenis kelamin secara mayoritas memiliki tekanan darah normal.

3. Kelompok usia 45-54 tahun merupakan kelompok mayoritas dengan lingkar pinggang tidak normal. 
4. Perempuan lebih banyak memiliki lingkar pinggang yang tidak normal sedangkan responden laki-laki lebih banyak memiliki lingkar pinggang normal.

5. Tidak terdapat hubungan antara lingkar pinggang dengan tekanan darah ( $p$ value $=$ $0,651)$.

\section{Saran}

1. Bagi Dinas Kesehatan Kota Lhokseumawe disarankan untuk terus melakukan upaya peningkatan derajat kesehatan masyarakat.

2. Bagi masyararakat disarankan untuk menjaga ukuran lingkar pinggang normal agar dapat terhindar dari penyakit yang terkait dengan pertambahan usia.

3. Bagi peneliti selanjutnya diharapkan dapat meneruskan penelitian ini lebih lanjut dan hasil penelitian ini dapat dikembangkan serta dijadikan acuan untuk penelitian tentang lingkar pinggang dan tekanan darah.

\section{DAFTAR PUSTAKA}

1. Setiati, S, Alwi, I, Sudoyo, AW, Simadibrata, M, Setyohadi, B, \& Syam, FA. Buku Ajar Ilmu Penyakit Dalam. Jakarta: Interna Publishing, 2014.

2. World Health Organization. A global brief on hypertension, Silent Killer, Global Public Health Crisis. Geneva: World Health Organization, 2013.

3. World Health Organization. Expert meeting on population sodium reduction srategies for prevention and control of noncommunicable disease in the south-east asia region. Geneva: World Health Organization, 2012.

4. Kementrian Kesehatan RI. Laporan Riskesdas. Jakarta :Kementrian Kesehatan RI, 2013.

5. Dinas Kesehatan Kota Lhokseumawe. Data kasusdankematianpenyakittidakmenularkotaLhokseumawetahun 2015. Lhokseumawe, 2015.

6. Jameson, JL \& Loscalzo, J. Harrison Nefrologi dan Gangguan Asam Basa. Jakarta: EGC, 2013.

7. Liubov, BN, Sohar, E \&Laor, A,Neck circumference as a simple screening measure for identifying overweight and obese patients, The North Association for The study of Obesity 2012, 9 (8): 1071-1076.

8. Boivin, Brochu \& Marceau, $\mathrm{P}$, Regional differences in adipose tissue metabolism in obese men. Metabolism clinical and experimental 2007. 56: 533-540.

9. Supariasa, N, Bakri, B \& Fajar, I. Penilaian Status Gizi. Jakarta: EGC 2002

10. Jalal, F, Liputo, N, Susanti, N \& Oenzil, F. Hubungan lingkar pinggang dengan kadar gula darah, trigliserida, dan tekanan darah. Universitas Andalas. 2006.

11. Bell, Ge, K \& Popkin, BM 2001, 'Weight gain and its predictors in Chinese adults. 'International Journal of Obesity2001, 25(7): 1079-1086.

12. Gharipour, M, Sarrafzadegan, N, Sadeghi, M, Andalib, E, Talaie, M, Shafie, D, \& Aghababaie, E, Predictors of metabolic syndrome in the iranian population: waist circumference, body mass index, or waist to hip ratio?, Hindawi, 2013,(198384): 4. 
13. Sunarti \& Maryani, E. Rasio lingkar pinggang dan pinggul dengan penyakit jantung koroner di RSUD kabupaten Sukoharjo, Buletin Penelitian Sistem Kesehatan2013, 16 (1): 73-82.

14. Anggara, DFH \& Prayitno, Faktor-faktor yang berhubungan dengan tekanan darah di Puskesmas Telaga Murni Cikarang Barat', Jurnal Ilmiah Kesehatan2013, 5 (1)

15. Bustan, MN,Epidemiologi Penyakit Tidak Menular. Jakarta: Rineka Cipta, 1997.

16. Muniroh, Lailatul, Wirjatmadi, Bambang, \& Kuntoro, Pengaruh pemberian jus buah belimbing dan mentimun terhadap penurunan tekanan darah sistolik dan diastolik penderita hipertensi, The Indonesian Journal of Public Health 2007, 4 (1).

17. Kane, RL, Ouslander, JG \& Abrass, IB, Essentials of Clinical Geriatrics. McGrawHill Inc, New York. 2004.

18. Andarmoyo, S \& Nurhayati, T, Laki-laki dan riwayat keluarga dengan penyakit jantung koroner berisiko terhadap penyakit jantung koroner, Artikel Penelitian, Fakultas Ilmu Kesehatan Universitas Muhammadiyah Ponorogo, Ponorogo. 2013.

19. Debra, AK, Medical nutrition in hypertension, dalam Krause's food, nutrition and diet therapy, Saunders, Philadelphia. 2004.

20. Sugianti, E, Faktor risiko obesitas sentral pada orang dewasa di Sulawesi Utara, Gorontalo dan DKI Jakarta, Artikel Penelitian, Departemen Gizi Masyarakat IPB, Bogor. 2009.

21. Aprilia, M, Hubungan pengukuran rasio lingkar pinggang terhadap tinggi badan badan dengan glukosa darah puasa lansia, Skripsi, Fakultas Kedokteran Universitas Diponegoro, Semarang. 2010.

22. Martins, IS \& Marinho, SP, The potential of central obesity antropometric indicators as diagnostic tools, Rev Saúde Pública 2003, 37(6): 760-767.

23. Janghorbani, M, Amini, M, Willett, CW, Gouya, MM, Delavari, A, Alikhani, S, \& Mahdavi, First nationwide survey of prevalence of overweight, underweight and abdominal obesity in iranian adults, Obesity 2007, 15(11): 797-2808.

24. Kantachuvessiri, A, Sirivichayakul, C, KaewKungwal J., Tungtrongchitr R, \& Lotrakul M, Factors associated with obesity among workers in a metropolitan waterworks authority, South east Asian J Trop Med Public Health 2005, 36(4).

25. Lipoeto, NI, Yerizel, E, Edward, Z, \&Widuri, I, Hubungan nilai antropometri dengan kadar glukosa darah, Medika 2007.

26. Amelinda, RT \& Wirawanni, Y 2014, Hubungan lingkar leher dan lingkar pinggang dengan kadar trigliserida orang dewasa di SMA Negeri 2 Semarang dan SMP Negeri 9 Semarang, Journal of Nutrition College. 2014, 3(4): 653.

27. World Health Organization. Obesity: Preventing and managing the global epidemic: report of aWHO consultation, Geneva : World Health Organization, 2000.

28. Kautsar, F, Syam, A Salam, A, Obesitas, Asupan Natrium dan Kalium terhadap Tekanan Darah Mahasiswa, Jurnal MKMI 2014, 10(4): 187-192.

29. Oviyanti, PN , Hubungan antara lingkar pinggang dan rasio lingkar pinggang panggul dengan tekanan darah pada subjek usia dewasa, Skripsi, Fakultas Kedokteran Universitas Sebelas Maret. 2010.

30. Yalcin, BM., Sahin, EM. \& Yalcin, E, Which anthropometric measurement is most closely related to elevated blood pressure, Fam Pract 2005,22(5): 541-547. 